\title{
Przesłanka negatywna wznowienia postępowania administracyjnego a rozpoznanie sprawy
}

\author{
Wyrok Naczelnego Sądu Administracyjnego z dnia 17 października 2017 r., \\ II OSK 2644/16
}

Jeżeli organ ustali, że decyzja ostateczna została wydana w postępowaniu dotkniętym kwalifikowaną wadliwością wyliczoną w art. 145 § 1 k.p.a., obowiązany jest do ponownego rozpoznania sprawy, z tym że $w$ razie gdy wystąpi przesłanka przedawnienia, nie może uchylić decyzji, a wyłącznie stwierdzić, że decyzja została wydana z naruszeniem prawa oraz wskazaniem, z jakiego powodu nie uchylił decyzji.

\section{Krzysztof Sobieralski}

Uniwersytet Wrocławski

krzysztof.sobieralski@uwr.edu.pl

ORCID: 0000-0002-2412-6674

https://doi.org/10.26881/gsp.2020.2.15

\section{Glosa}

W glosowanym wyroku' Naczelny Sąd Administracyjny (NSA) wyraził pogląd co do sposobu interpretacji negatywnych przesłanek wznowienia postępowania administracyjnego. Pogląd ten zasługuje na pełną aprobatę.

Konstrukcja prawna przesłanek negatywnych wznowienia postępowania administracyjnego jest odmienna od konstrukcji prawnej negatywnych przesłanek wznowienia postępowania sądowoadministracyjnego czy też postępowania cywilnego. Założeniem dopuszczalności każdego postępowania jest istnienie określonych przesłanek prawnych. Założeniem niedopuszczalności postępowania jest a contrario nieistnienie przesłanek warunkujących jego dopuszczalność. Wynika to z tezy, że przesłanki prawne mogą być ujęte $w$ formie negatywnej (ujemnej, tj. w formie braku pewnych warunków) lub w formie pozytywnej (dodatniej, tj. w formie potrzeby ich istnienia). Brak każdej przesłanki dodatniej staje się przeszkodą procesową². Aby możliwe było

\footnotetext{
1 Wyrok NSA z dnia 17 października 2017 r., II OSK 2644/16, Centralna Baza Orzeczeń Sądów Administracyjnych (CBOSA).

2 L. Klat-Wertelecka, Niedopuszczalność egzekucji administracyjnej, Wrocław 2009, s. 128.
} 
prowadzenie postępowania, niezbędne jest istnienie przesłanek pozytywnych oraz nieistnienie przesłanek negatywnych. Jednak w nauce postępowania administracyjnego kontrowersje powstają już na płaszczyźnie terminologicznej. Zdaniem Zbigniewa R. Kmiecika, posługiwanie się określeniem „negatywne przesłanki wznowienia postępowania" w stosunku do okoliczności wymienionych w art. 146 kodeksu postępowania administracyjnego ${ }^{3}$ - jest „nieprecyzyjne, jeśli nie po prostu błędne”, z uwagi na fakt, że ich wystąpienie nie uniemożliwia wznowienia postępowania, a jedynie blokuje możliwość uchylenia decyzji weryfikowanej w trybie wznowieniowym ${ }^{4}$. Jakkolwiek prawidłowa jest konstatacja Autora w zakresie skutków wystąpienia przesłanek art. 146 k.p.a., co znajduje potwierdzenie w literalnym brzmieniu przepisu, to argumentem w obronie zasadności posługiwania się tym określeniem może być sama istota instytucji wznowienia postępowania administracyjnego. Jak wskazuje Wacław Dawidowicz: „Instytucja wznowienia postępowania ma na celu stworzenie prawnej możliwości przeprowadzenia ponownego postępowania wyjaśniającego i ponownego rozstrzygnięcia sprawy administracyjnej, w której została już wydana decyzja ostateczna"5. Jeśli zatem sens instytucji wznowienia postępowania administracyjnego sprowadza się do możliwości ponownego merytorycznego rozpoznania sprawy administracyjnej zakończonej decyzją ostateczną, jak również ponownego jej rozstrzygnięcia, a to ostatnie uzależnione jest od uprzedniej eliminacji z obrotu prawnego decyzji wydanej w postępowaniu głównym poprzez zastosowanie wobec niej sankcji wzruszalności, to przesłanki, których wystąpienie stoi temu na przeszkodzie, zasługują na miano „negatywnych przesłanek wznowienia postępowania". Słusznie wobec tego Barbara Adamiak utożsamia przesłanki wznowienia postępowania z przesłankami, których wystąpienie „otwiera możliwość prawną ponownego rozpoznania i rozstrzygnięcia sprawy rozstrzygniętej decyzją ostateczną" ${ }^{6}$, a nie tymi, które umożliwiają lub uniemożliwiają wszczęcie postępowania wznowieniowego.

Przepisy k.p.a. statuują dwie negatywne przesłanki wznowienia postępowania administracyjnego, a są nimi: przedawnienie (upływ dziesięciu lub pięciu lat od dnia doręczenia lub ogłoszenia decyzji w zależności od podstawy wznowienia) oraz ustalenie przez organ administracji publicznej, że w wyniku wznowienia postępowania mogłaby

\footnotetext{
3 Ustawa z dnia 14 czerwca 1960 r. - Kodeks postępowania administracyjnego (Dz. U. z 2020 r., poz. 256 ze zm.; dalej: k.p.a.).

4 Z.R. Kmiecik, O charakterze decyzji administracyjnych kończacych wznowione postępowanie [w:] Prawo administracyjne wobec współczesnych wyzwań. Księga jubileuszowa poświęcona prof. Markowi Wierzbowskiemu, red. J. Jagielski, D. Kijowski, M. Grzywacz, Warszawa 2018, s. 274; podobnie: R. Kędziora, Ogólne postępowania administracyjne, Warszawa 2017, s. 405. Zdaniem Z.R. Kmiecika, określenie „negatywne przesłanki wznowienia postępowania” mogłoby być odnoszone do okoliczności, które wyłączają dopuszczalność procedowania przez organ w trybie wznowienia postępowania, takich jak np. funkcjonowanie w obrocie prawomocnego wyroku sądu administracyjnego oddalającego skargę na decyzję (z zastrzeżeniem, że nie dotyczy to wszystkich podstaw wznowienia postępowania z art. $145 \S 1$ k.p.a.) - zob. idem, Warunki dopuszczalności wznowienia postępowania administracyjnego [w:] Jednostka wobec władczej ingerencji administracji publicznej. Księga jubileuszowa dedykowana profesor Barbarze Adamiak, red. J. Korczak, K. Sobieralski, Wrocław 2019 r., s. 255 i n.

5 W. Dawidowicz, Postępowanie administracyjne. Zarys wykładu, Warszawa 1983, s. 242.

6 B. Adamiak [w:] eadem, J. Borkowski, KPA. Komentarz, Warszawa 2017, s. 759.
} 
zapaść wyłącznie decyzja odpowiadająca w swej istocie decyzji dotychczasowej (przesłanka o charakterze merytorycznym ${ }^{7}$ ). Komentowany wyrok dotyczy pierwszej z nich.

Jakkolwiek ocena wystąpienia przesłanki przedawnienia przez organ prowadzący postępowanie wznowieniowe nie powinna nastręczać trudności praktycznych, to już skutek, jaki powoduje, nie jest jednolicie postrzegany. Powstaje pytanie: jak powinien zachować się organ, gdy ustali upływ terminów, o których mowa w art. 146 § 1 k.p.a? W pierwszej kolejności zastrzec należy, że okoliczność ta nie może w żadnym razie być przedmiotem oceny organu, zanim nie przesądzi on zaistnienia pozytywnych przesłanek wznowienia postępowania (art. 145 § 1, art. 145a i art. 145b k.p.a.). W początkowej fazie postępowania wznowieniowego - czyli w postępowaniu co do przyczyn wznowienia - przesłanka przedawnienia pozostaje zatem prawnie indyferentna dla przebiegu postępowania. Gdy organ podejmie postępowanie wznowieniowe i dojdzie do przekonania, że upłynął termin przedawnienia, to fakt ten nie zwalnia go z obowiązku prowadzenia postępowania co do przyczyn wznowienia․ Przesłanka ta podlega uwzględnieniu dopiero na późniejszym etapie postępowania, a jej wystąpienie uniemożliwia uchylenie decyzji weryfikowanej w postępowaniu wznowieniowym i skutkuje rozstrzygnięciem stwierdzającym wydanie zaskarżonej decyzji z naruszeniem prawa ze wskazaniem okoliczności, z powodu których organ nie uchylił tej decyzji (art. 151 § 2 k.p.a.).

Na tle interpretacji art. $146 \S 1$ k.p.a. zarysowały się dwa stanowiska. Pierwsze z nich prezentuje Tadeusz Kiełkowski, którego zdaniem upływ terminu przedawnienia, wbrew literalnemu brzmieniu art. $146 \S 1$ k.p.a., skutkuje nie tylko niedopuszczalnością uchylenia decyzji dotychczasowej, lecz także powoduje, że organ nie może przejść do tego etapu postępowania wznowieniowego, w którym sprawa miałaby podlegać ponownemu rozpatrzeniu i rozstrzygnięciu. Poczynienie pozytywnych ustaleń co do wystąpienia przesłanki przedawnienia - w ocenie Autora - obliguje organ do odstąpienia od badania istoty sprawy ${ }^{9}$. W nieco podobnym tonie wypowiada się również Małgorzata Jaśkowska, według której prowadzenie postępowania po upływie okresu przedawnienia narusza zasadę trwałości decyzji administracyjnej. Autorka ta przyjmuje, że upływ terminu określonego w art. 146 k.p.a. ogranicza możliwość ponownego rozstrzygnięcia co do istoty sprawy, nie twierdzi jednak, że wyklucza rozpoznanie sprawy ${ }^{10}$. Stanowisko to znalazło aprobatę w wyroku NSA ${ }^{11}$, w którym wskazano, że w sytuacji gdy zachodzi przeszkoda do uchylenia decyzji z § 1 art. 146 k.p.a., organy nie mają podstawy do prowadzenia postępowania co do istoty sprawy. Podstawą rozstrzygnięcia jest bowiem stwierdzony fakt naruszenia prawa przy wydaniu skarżonej decyzji

7 B. Adamiak, Wyroki Naczelnego Sądu Administracyjnego w sprawach z zakresu samorzadu terytorialnego, Sam. Teryt. 1997, nr 4, s. 27.

8 Wyrok NSA z dnia 13 maja 2014 r., II GSK 451/13, LEX nr 1481810.

9 T. Kiełkowski, Granice wznowionego postępowania administracyjnego w orzecznictwie sądów administracyjnych, „Przegląd Prawa Publicznego" 2015, nr 10, s. 55; idem [w:] Postępowanie administracyjne, red. T. Woś, Warszawa 2017, s. 549.

10 M. Jaśkowska [w:] eadem, A. Wróbel, Kodeks postępowania administracyjnego. Komentarz, Warszawa 2016, s. 796; oraz ibidem, Warszawa 2018, s. 1000-1001.

11 Wyrok NSA z dnia 14 marca 2017 r., II OSK 1783/15, LEX nr 2301631; podobnie: wyrok NSA z dnia 28 września 2010 r., I OSK 1604/09, LEX nr 745097. 
oraz wskazana przyczyna uniemożliwiająca uchylenie tej decyzji. Przedstawione stanowisko odbiega od tezy przyjętej przez NSA w komentowanym wyroku. Stanowisko przeciwne prezentuje w nauce między innymi B. Adamiak, której zdaniem wydanie decyzji na podstawie art. $151 \S 2$ k.p.a. dopuszczalne jest wyłącznie po przeprowadzeniu postępowania co do podstaw wznowienia i rozstrzygnięcia istoty sprawy ${ }^{12}$. Określona w art. $146 \S 1$ k.p.a. przesłanka przedawnienia w żadnym razie nie wyłącza obowiązku ponownego rozpoznania sprawy, a jedynie zakazuje uchylenia decyzji. Stąd w razie gdy organ ustali, że decyzja ostateczna została wydana w postępowaniu dotkniętym kwalifikowaną wadliwością wyliczoną w art. 145 § 1 k.p.a., obowiązany jest do ponownego rozpoznania sprawy, z tym że w razie gdy wystąpi przesłanka przedawnienia, nie może uchylić decyzji. Jedyną możliwością jest wówczas stwierdzenie, że decyzja została wydana z naruszeniem prawa, ze wskazaniem, z jakiego powodu organ jej nie uchylił.

Należy w pełni zgodzić się z drugim stanowiskiem. Ustalenie przez organ prowadzący postępowanie wznowieniowe, że wystąpiły pozytywne przesłanki (podstawy) wznowienia, aktualizuje bowiem jego obowiązek w zakresie ponownego rozpatrzenia sprawy zakończonej decyzją ostateczną, a więc przeprowadzenia typowego postępowania jurysdykcyjnego ${ }^{13}$. W postępowaniu tym nie może zabraknąć jednego z jego stadiów, tj. stadium postępowania wyjaśniającego, które obejmuje ciąg czynności procesowych zorientowanych na ustalenie stanu faktycznego sprawy, dającego podstawę do zastosowania normy prawa materialnego. Przesłanka przedawnienia ma znaczenie dopiero w trzecim stadium postępowania, a więc w stadium podjęcia decyzji.

Katalog rozstrzygnięć, które mogą zapaść w postępowaniu wznowieniowym, obejmuje trzy rodzaje aktów. Po pierwsze, decyzję odmawiającą uchylenia decyzji dotychczasowej, wydawaną na skutek stwierdzenia braku podstaw do jej uchylenia na podstawie art. $145 \S 1$, art. 145a lub art. 145b - art. $151 \S 1$ pkt 1 k.p.a. Po drugie, decyzję uchylającą decyzję dotychczasową i rozstrzygającą na nowo o istocie sprawy, wydawaną na skutek stwierdzenia zaistnienia podstaw do jej uchylenia na podstawie art. 145 § 1, art. 145a lub art. 145b - art. 151 § 1 pkt 2 k.p.a. Po trzecie, decyzję stwierdzającą wydanie zaskarżonej decyzji z naruszeniem prawa ze wskazaniem okoliczności, z powodu których organ nie uchylił decyzji, wydawaną w przypadku, gdy w wyniku wznowienia postępowania nie można uchylić decyzji na skutek okoliczności, o których mowa w art. 146 - art. 151 § 2 k.p.a. Wystąpienie przesłanki przedawnienia, podobnie jak drugiej przesłanki negatywnej wznowienia postępowania, nie zezwala organowi na wydanie decyzji uchylającej decyzję dotychczasową i rozstrzygającej na nowo o istocie sprawy. Wynika to explicite z treści art. 146 § 1 k.p.a., w którym ustawodawca stanowi: „uchylenie decyzji (...) nie może nastąpić.... Stwierdzenie niezgodności z prawem decyzji wchodzi zatem „w jej w miejsce” ${ }^{\prime 14}$. Pozostałe rodzaje rozstrzygnięć,

12 B. Adamiak [w:] eadem, J. Borkowski, KPA..., Warszawa 2017, s. 816.

13 J. Zimmermann, Aksjomaty prawa administracyjnego, Warszawa 2017, s. 229.

14 E. Bojanowski, Stwierdzenie wydania decyzji administracyjnej z naruszeniem prawa w kodeksie postępowania administracyjnego [w:] Procedura administracyjna wobec wyzwań współczesności. Profesorowi zwyczajnemu dr. hab. Januszowi Borkowskiemu przyjaciele i uczniowie, Łódź 2004, s. 51-52. 
o których mowa powyżej, z uwagi na fakt, że nie przewidują eliminacji zaskarżonej decyzji z obrotu prawnego, są w pełni dopuszczalne. Stąd też w żadnym razie nie można zgodzić się ze stanowiskiem, jakie zajął NSA w wyroku ${ }^{15}$, w którym przyjął: „Po upływie okresu przedawnienia w sprawie rozpoznawanej w trybie wznowienia postępowania, organ administracji publicznej traci (...) uprawnienie nie tylko do uchylenia decyzji, ale i do odmowy uchylenia decyzji dotychczasowej wydanej w postępowaniu zwyczajnym, z powodu stwierdzenia przez organ administracji braku podstaw do jej uchylenia, gdyż byłoby to rozstrzygnięcie co do istoty sprawy. Akceptacja poglądu przeciwnego oznaczałaby, że po upływie okresu przedawnienia, kiedy organ nie mógł już uchylić decyzji (art. 146 § 1 in fine), nadal może toczyć się postępowanie badające sprawę co do istoty". Zgodzić się należy zatem z Wojciechem Chróścielewskim, że upływ terminu przedawnienia nie stoi nie przeszkodzie odmowie uchylenia decyzji dotychczasowej ${ }^{16}$.

Dla zachowania terminów zakreślonych w art. $146 \S 1$ k.p.a. konieczne jest wydanie i doręczenie w tym czasie decyzji przez organy obu instancji, jeśli orzeczenie organu pierwszej instancji poddane zostało kontroli instancyjnej. O ile celem postępowania wznowieniowego jest eliminacja wadliwości procesowych, a w konsekwencji zmiana ostatecznego orzeczenia organu administracji publicznej poprzez nałożenie na nie sankcji wzruszalności, o tyle upływ czasu przewidzianego w art. $146 \S 1$ k.p.a. stabilizuje w obrocie prawnym zarówno to rozstrzygnięcie, jak i ukształtowane na jego podstawie stosunki administracyjnoprawne. Ustawodawca dąży więc do nienaruszalności stosunków prawnych, gdy przetrwały już określony czas. Przyjęcie koncepcji wzruszalności decyzji administracyjnej oznacza, że nałożenie tej sankcji na decyzję (postanowienie) pozbawia ją możliwości wywoływania skutków ex nunc - na przyszłość. Zaistnienie przesłanki negatywnej oznacza, że nie można naznaczyć orzeczenia sankcją wzruszalności w trybie wznowienia postępowania administracyjnego.

Termin określony w art. 146 § 1 k.p.a. nie może upłynąć w chwili, gdy orzeka się w trybie wznowieniowym - a właściwie w ramach wznowionego postępowania. Uchylenie decyzji dotychczasowej w trybie wznowienia postępowania administracyjnego niweczy ex nunc skutki decyzji uchylonej (wzruszonej), a więc jej dalszą wykonalność w znaczeniu formalnym oraz w znaczeniu materialnym. Rozstrzygnięcie, o którym mowa w art. 151 § 1 k.p.a. wydawane jest w pierwszej instancji, podlega więc kontroli instancyjnej na skutek złożenia przez stronę odwołania. Odwołanie jest zwykłym środkiem zaskarżenia o charakterze względnie suspensywnym. Jego złożenie powoduje wstrzymanie wykonania zaskarżonej decyzji, a organ odwoławczy przechodzi do ponownego merytorycznego rozpoznania i rozstrzygnięcia tej samej sprawy administracyjnej procesowej - sprawy wznowieniowej. Organ odwoławczy wstępuje więc w te kompetencje, które mocą art. 150 § 1 i art. 151 k.p.a. posiadał właściwy do wznowienia

\footnotetext{
15 Wyrok NSA z dnia 30 kwietnia 2009 r., II OSK 124/09, LEX nr 555045.

16 W. Chróścielewski [w:] Kodeks postępowania administracyjnego. Komentarz, red. idem, Z. Kmieciak, Warszawa 2019, s. 810-811; podobnie: Z.R. Kmiecik, Glosa do wyroku Wojewódzkiego Sądu Administracyjnego w Warszawie z dnia 13 marca 2012 r., II SA/Wa 2202/11, OSP 2014, z. 4, s. 525.
} 
postępowania organ pierwszej instancji. Organ odwoławczy musi zatem również przestrzegać zakazu sformułowanego $w$ art. 146 k.p.a. Termin określony w tym przepisie, mimo że został umieszczony w ustawie procesowej, nie jest terminem procesowym. Jego upływ pozbawia bowiem organ administracji publicznej kompetencji do ponownego rozstrzygnięcia w trybie procesowym sprawy administracyjnej materialnej. Sprawa musi zostać rozpoznana (m.in. po to właśnie, aby ustalić, czy ten termin nie upłynął), ale merytoryczne rozstrzygnięcie nie może mieć miejsca. Termin ten posiada w istocie charakter materialnoprawny, gdyż jego upływ powoduje skutek materialnoprawny rozumiany jako utrzymanie faktycznej możliwości zrealizowania uprawnień lub obowiązków zawartych w treści decyzji poddanej procedurze wznowienia postępowania administracyjnego.

Cechą właściwą decyzji administracyjnej jest uzewnętrznienie oświadczenia woli kompetentnego organu administracji publicznej. Następuje ono przez zakomunikowanie woli jednostce, której uprawnienia i obowiązki kształtuje decyzja administracyjna. Z rozwiązań przyjętych w przepisach k.p.a. wynika, że wyłączną formą zakomunikowania oświadczenia woli jednostce jest doręczenie lub ogłoszenie. Przepis art. 146 $\S 1$ k.p.a., określając początek biegu wskazanego w nim terminu, posługuje się pojęciem "dnia doręczenia lub ogłoszenia decyzji", nie wskazuje cech tego doręczenia lub ogłoszenia, ani tym bardziej jego adresatów. Pozwala to na przyjęcie, że chodzi o doręczenie lub ogłoszenie decyzji wobec osób biorących udział w postępowaniu, które podlega wznowieniu. Za taką interpretacją art. $146 \S 1$ k.p.a. przemawia również objęcie nim przesłanki wznowienia wskazanej w art. 145 § 1 pkt 4 k.p.a. ${ }^{17}$ Upływ terminów określonych w art. $146 \S 1$ k.p.a. od dnia doręczenia lub ogłoszenia decyzji stronom, jako przesłanka negatywna wznowienia postępowania administracyjnego, jest bezwarunkowy - niezależny od okoliczności, które to spowodowały - i oznacza bezwzględny zakaz uchylenia decyzji (postanowienia) jako rodzaju merytorycznego orzekania w sprawie. Nie oznacza natomiast zakazu rozpoznania sprawy administracyjnej materialnej. Organ administracji publicznej traci bowiem kompetencję tylko do uchylenia decyzji, ale już nie do odmowy uchylenia decyzji dotychczasowej. Problem wykonalności decyzji (również postanowienia) wydanej w wyniku wznowienia postępowania administracyjnego dotyczy $w$ istocie rozstrzygnięć podejmowanych na podstawie art. 151 § 1 k.p.a. Wykonalność tych orzeczeń uzależniona jest od tego, czy zdołają one uzyskać przymiot ostateczności przed upływem terminów wskazanych w art. $146 \S 1$ k.p.a. Decyzja organu odwoławczego (organu drugiej instancji) uzyskuje przymiot ostateczności z chwilą jej doręczenia stronie. Tylko ten moment będzie zatem miarodajny dla oceny zaistnienia negatywnej przesłanki wznowienia postępowania administracyjnego.

Jeżeli w wyniku rozpoznania sprawy administracyjnej procesowej właściwy organ administracji publicznej stwierdzi zaistnienie przesłanek negatywnych wznowienia postępowania administracyjnego, to ich zaistnienie nie będzie stanowiło przeszkody do wznowienia postępowania zarówno na wniosek strony, jak i z urzędu (wynika to

17 Por. wyrok NSA z dnia 24 stycznia 2002 r., I SA 1526/00, LEX nr 82800. 
wprost z treści przepisów art. 146 k.p.a.). Negatywne przesłanki wznowienia postępowania nie decydują zatem o dopuszczalności wznowienia. Co istotne, zaistnienie przesłanek negatywnych nie stanowi również przeszkody do merytorycznego rozpoznania sprawy administracyjnej materialnej w postępowaniu wznowionym. To właśnie w toku rozpoznania sprawy administracyjnej materialnej można dopiero stwierdzić, czy zachodzą przesłanki negatywne. Przesłanki te posiadają charakter bardziej materialny niż formalny. Zarówno bowiem upływ określonego ustawowo terminu od doręczenia lub ogłoszenia decyzji ostatecznej, jak i okoliczność - czy w wyniku wznowienia mogłaby zapaść jedynie decyzja odpowiadająca w swej istocie dotychczasowej decyzji (tożsamość treściowa rozstrzygnięcia), stanowią elementy stanu faktycznego sprawy, które mogą zostać ustalone jedynie w wyniku jej rozpoznania. W przypadku stwierdzenia przez właściwy organ w toku wznowionego postępowania zaistnienia którejś z przesłanek negatywnych, następuje (lub nastąpiło) merytoryczne rozpoznanie sprawy administracyjnej materialnej, nie dochodzi jedynie do ponownego merytorycznego rozstrzygnięcia tej sprawy materialnej poprzez uchylenie dotychczasowego rozstrzygnięcia i orzeczenie co do istoty sprawy. Warto podkreślić, że zaistnienie przesłanek negatywnych stabilizuje w obrocie prawnym skutki ostatecznych decyzji administracyjnych (postanowień). Można je zatem uznać za element systemu gwarancji ochrony praw nabytych przez jednostkę z rozstrzygnięć ostatecznych. Stanowią wyraz przyjętego przez ustawodawcę kompromisu między potrzebą (zasadą) ochrony praworządności w działaniu organów administracji publicznej oraz potrzebą (zasadą) ochrony praw nabytych strony. Przesłanki negatywne wznowienia postępowania administracyjnego, wykluczając jedynie ponowne rozstrzygnięcie sprawy administracyjnej materialnej, zamykają możliwość ingerencji w sferę prawnie ukształtowaną. Gdyby jednak tak ukształtowana sfera stanowiła dla jednostki źródło szkody, otwarta pozostaje kwestia wystąpienia z roszczeniem odszkodowawczym.

\section{Literatura}

Adamiak B., Wyroki Naczelnego Sądu Administracyjnego w sprawach z zakresu samorządu terytorialnego, Sam. Teryt. 1997, $\mathrm{nr} 4$.

Adamiak B., Borkowski J., KPA. Komentarz, Warszawa 2017.

Bojanowski E., Stwierdzenie wydania decyzji administracyjnej z naruszeniem prawa w kodeksie postępowania administracyjnego [w:] Procedura administracyjna wobec wyzwań współczesności. Profesorowi zwyczajnemu dr. hab. Januszowi Borkowskiemu przyjaciele i uczniowie, Łódź 2004.

Dawidowicz W., Postępowanie administracyjne. Zarys wykładu, Warszawa 1983.

Kędziora R., Ogólne postępowania administracyjne, Warszawa 2017.

Kiełkowski T., Granice wznowionego postępowania administracyjnego w orzecznictwie sądów administracyjnych, „Przegląd Prawa Publicznego” 2015, nr 10.

Klat-Wertelecka L., Niedopuszczalność egzekucji administracyjnej, Wrocław 2009.

Kmiecik Z.R., Glosa do wyroku Wojewódzkiego Sądu Administracyjnego w Warszawie z dnia 13 marca 2012 r., Il SA/Wa 2202/11 ,"Orzecznictwo Sądów Polskich” 2014, z. 4. 
Kmiecik Z.R., O charakterze decyzji administracyjnych kończących wznowione postępowanie [w:] Prawo administracyjne wobec współczesnych wyzwań. Księga jubileuszowa poświęcona prof. Markowi Wierzbowskiemu, red. J. Jagielski, D. Kijowski, M. Grzywacz, Warszawa 2018.

Kmiecik Z.R., Warunki dopuszczalności wznowienia postępowania administracyjnego [w:] Jednostka wobec władczej ingerencji organów administracji publicznej. Księga jubileuszowa dedykowana profesor Barbarze Adamiak, red. J. Korczak, K. Sobieralski, Wrocław 2019.

Kodeks postępowania administracyjnego. Komentarz, red. Z. Kmieciak, W. Chróścielewski, Warszawa 2019.

Postępowanie administracyjne, red. T. Woś, Warszawa 2017.

Wróbel A., Jaśkowska M., Kodeks postępowania administracyjnego. Komentarz, Warszawa 2016.

Wróbel A., Jaśkowska M., Kodeks postępowania administracyjnego. Komentarz, Warszawa 2018.

Zimmermann J., Aksjomaty prawa administracyjnego, Warszawa 2017.

\section{Streszczenie}

\section{Krzysztof Sobieralski}

Przesłanka negatywna wznowienia postępowania administracyjnego a rozpoznanie sprawy

Przesłanki negatywne wznowienia postępowania administracyjnego, określone w art. 146 k.p.a., podobnie jak przesłanki pozytywne, wymienione w art. 145-145b k.p.a., stanowią elementy stanu faktycznego sprawy, które mogą zostać ustalone jedynie w wyniku jej rozpoznania.

W przypadku stwierdzenia przez właściwy organ w toku wznowionego postępowania zaistnienia którejś z przesłanek negatywnych, następuje (lub nastąpiło) merytoryczne rozpoznanie sprawy administracyjnej materialnej, nie dochodzi jedynie do ponownego merytorycznego rozstrzygnięcia tej sprawy materialnej poprzez uchylenie dotychczasowego rozstrzygnięcia i orzeczenie co do istoty sprawy. Zaistnienie przesłanek negatywnych stabilizuje w obrocie prawnym skutki ostatecznych decyzji administracyjnych (postanowień).

\section{Summary}

\section{Krzysztof Sobieralski}

\section{Negative ground of the reopened administrative proceedings and the examination of the case}

Finding that there is a negative ground pursuant to art. 146 of Code of Administrative Procedure, may take place only as a result of the examination of the case in the reopened proceedings.

If the authority determines that the final decision has been issued in proceedings affected by a qualified defect listed in art. $145 \S 1$ of the Code of Administrative Procedure, it is obliged to reconsider the case, except that if there is a condition of limitation, it may not quash the decision, but only state that the decision was issued in contravention to the law and the authority shall indicate circumstances due to which the authority did not quash the decision. 
Słowa kluczowe: wznowienie postępowania administracyjnego, rozpoznanie sprawy, organ administracji publicznej, decyzja administracyjna, przesłanki negatywne

Keywords: reopening of administrative proceedings, consideration of the case, public administration authority, administrative decision, negative prerequisites 
